\title{
Climate-smart agricultural practices in Ethiopia: implications of mitigation of greenhouse gas emissions a review paper
}

\author{
Wakshum Shiferaw
}

Arba Minch University, College of Agricultural Sciences, Natural Resources Management, P.O.Box 21, Arba Minch, Ethiopia

E-mail: waaqsh@yahoo.com

\begin{abstract}
This paper aimed to assess climate smart agricultural practices in Ethiopia, discuss the contribution of climate smart agricultural practices for mitigation of greenhouse gas emissions, and examine determinant factors of climate smart agricultural practices in mitigation of greenhouse gas emissions. Conservation agriculture, integrated soil fertility management, agroforestry, crop diversification, and improved livestock feed and feeding practices are among the best climate smart agricultural practices in Ethiopia. Combination of the adoption of climate smart agricultural practices such as no tillage, increased crop diversity and retaining crop residue on farm have a mitigation potential of increased SOC in non-flooded crops that change in significant ton of $\mathrm{CO}_{2} \mathrm{e} \mathrm{ha}^{-1}$ year-1. In addition, a mitigation potential of $\mathrm{CH}_{4}$ in reduced irrigation of paddy rice farms was also changed in ton $\mathrm{CO}_{2} \mathrm{e} \mathrm{ha}{ }^{-1}$ year ${ }^{-1}$. It was found that productivity enhancing interventions in the tropics could reduce emission intensity in dairy systems by up to $0.9 \mathrm{t} \mathrm{CO}_{2} \mathrm{e}$ per milk. Agroforestry practices and addition of organic fertilizers on the farm increased mitigation potential of $784093 \mathrm{t} \mathrm{CO}_{2} \mathrm{e}$ and $193050 \mathrm{t} \mathrm{CO}_{2} \mathrm{e}$ biomass of carbon and SOC per year respectively. Adoptions of climate smart agricultural practices are affected by different factors such as farming factors, technology inaccessibility, environmental factors, policy design and social expertise, negative attitudes and motivations of farmers, farmers' socio-demographic factors, and farmers' socioeconomic factors. To reverse the situations, preparation of targeted climate smart agricultural practices to areas that are likely to provide the greatest GHG reduction potential and demonstration of these practices to other areas should be encouraged so that other farmers will learn for similar agro-ecologies.
\end{abstract}

Keywords: Climate, Conservation agriculture, GHG emission, Livestock husbandry, Mitigation 


\section{Introduction}

Agriculture is the basic economic sector in Ethiopia in which most population relies for its social and economic development. Its contribution was $46.3 \%$ of the national GDP and $90 \%$ of foreign exchange earnings of the country (Adem et al., 2018). However, climate variability, change and related extreme events are adversely affecting agricultural production. Climate changes likely result in increased variability in precipitation and increase in temperature (Dendir and Simane, 2019). The variability in precipitation and increase of temperature are due to increases of greenhouse gas (GHG) emissions into the surrounding atmosphere.

It is estimated that agriculture and associated land use changes account for $24 \%$ of total global emissions (Niles et al., 2018 cited in Smith et al., 2014). However, excluding forestry and other land uses, agriculture contributes approximately 12\% of global GHG emissions (IFAD, 2019; Jantke et al., 2020). Methane $\left(\mathrm{CH}_{4}\right)$ and nitrous oxide $\left(\mathrm{N}_{2} \mathrm{O}\right)$ are the primary GHGs produced by agricultural activities, comprising about $55 \%$ and $45 \%$ of emissions from agriculture,

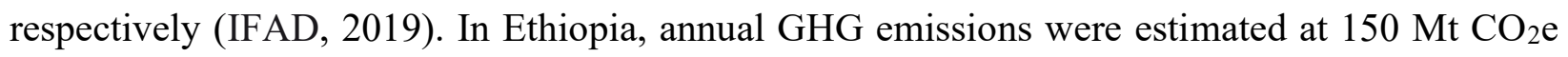
in 2010 , with $50 \%$ and $37 \%$ of these emissions resulting from the agricultural and forestry sectors respectively. In addition, livestock production accounted for more than $40 \%$ of the emissions in agriculture (FAO, 2016). Climate change has been caused by human activities like agriculture; particularly small-scale farming is both a contributor to greenhouse gas (GHG) emissions and a victim of the effects of climate change (Abegunde et al., 2019).

Climate smart agriculture (CSA) is an approach to agriculture that sustainably increases productivity, enhances adaptation and mitigates emissions of GHG (IFAD, 2019). On the other hand, there are inadequate research findings on climate smart agricultural (CSA) practices in Ethiopia for the various agro-ecology, soil type, rainfall pattern, farming system, temperature and moisture ranges. At all levels, data on climate smart agricultural (CSA) and conservation agriculture in particular are insufficient (FAO, 2016). Moreover, little research has reported about the status of climate smart agricultural (CSA) practices in mitigation of GHG emissions in Ethiopia. Thus, this review paper aimed to assess climate smart agricultural (CSA) practices in Ethiopia, take up lessons learned elsewhere or in Ethiopia and discuss the contribution of climate smart agricultural practices for mitigation of greenhouse gas emissions, and examine determinant factors of climate smart agricultural practices in mitigation of greenhouse gas emissions. Thus, 
the paper addresses relevant scientific information's based on evaluation of data collected from different journals, manuals and various report works.

\section{Climate and agriculture}

Agriculture is the main sector of the Ethiopian economy. Agriculture in Ethiopia includes crops, livestock, forestry, fisheries, apiculture and other natural resources. It is the most important sector of the national economy and the main source of livelihoods for $85 \%$ of the population (FAO, 2016). However, the production and productivity of agriculture in the country is highly vulnerable to climate variability (Dendir and Simane, 2019). Climate variables such as temperature, reduced rainfall, and increased rainfall variability reduces crop yield and threatens food security in low income and agriculture based economies (Gezie, 2019).

The effect of climate change is not only attributing in the reduction of crop yields and incomes but also human health of population who is engaged in agricultural production generally expected to be adverse (Komarek et al., 2019). In Ethiopia, climate change related health problems like mortality and morbidity due to floods and heat waves, vector-borne diseases, water-borne diseases, meningitis, and air pollution-related respiratory diseases are increasing (Simane et al., 2017).

Climate change has caused recurrent droughts and famines, flooding, expansion of desertification, loss of wetlands, loss of biodiversity, and shortage of water resulted in decline of agricultural production (Zegeye, 2018). IPCC (2013) depicts that spatial and temporal distribution of water resources become uneven due to global climate change effects. Other evidence indicates that the major impact of climate change on Ethiopia's economy will result from more frequent occurrence of extreme hydrologic events, which cause losses in both the agricultural and non-agricultural sectors (IFPRI, 2010). As a result, the patterns of climate change data show that rainfall is increasingly erratic with marked seasonal deficits when compared to long term past averages, droughts appear to be increasingly frequent, heavy rainfall events appear to be increasingly frequent, with changes in rainfall patterns, including decreased reliability and less predictability for agricultural activities (USAID, 2015).

Supposing that constant inputs of carbon to soils from vegetation, different estimate predict that expected climate changes for example changes of temperature, precipitation and evaporation will cause significant change in organic matter turnover and $\mathrm{CO}_{2}$ dynamics (Karmakar et al., 2016). Moreover, Daba et al. (2018) show that soil are complicatedly linked to the climate system 
through nitrogen, carbon, and hydrologic cycles and in consequence change in climate affect soil processes and properties. Climate change also resulted in increasing of soil, water bodies, and air pollutions and consequently impacts on agricultural production (Arora, 2019). Soil erosion by wind and water are also likely to increase as the result of climate change which removes the most fertile part of top soil (Brevik, 2013). Therefore, climate change impacts of on agriculture have significant consequences on livelihoods, food production, and the overall economy of countries. Climate changes are affecting particularly those with agriculture-based economies in the developing world like Ethiopia on crop production, livestock productivity, horticultural crops, aquaculture (fish production), and apiculture (Lemi and Hailu, 2019).

\subsection{Concepts and definitions of terminologies}

Climate smart agriculture (CSA) is a tactic for changing and reorienting agricultural systems to support food security under climate change as well as the reduction of GHG emissions from agricultural activities (Abegunde et al., 2019; Komarek et al., 2019). On the other hand, climate smart agriculture (CSA) is a very widely used term that reflects no climate-specific benefits and it contributes significantly to GHG emissions and at the same time is strongly affected by climate change has initiated the exploration of agricultural methods that are aligned with the maintenance of ecosystems (FAO, 2010; SLM, 2017). According to Neufeldt et al. (2013), climate-smart agriculture (CSA) consists of several agricultural practices that sustainably increase productivity, improve resource use efficiency, reduce exposure, vulnerability to climate variability, and reduce GHG emissions from agriculture.

Greenhouse gases (GHGs) emission is the release of gases in the form of carbon dioxide; methane and nitrous oxide are enormously into the atmosphere through these major sources such as deforestation, automobile, agriculture, industry, and organic waste (Arfin et al., 2015). Emissions of greenhouse gases (GHGs) is the most important driver of human induced climate change (Jantke et al., 2020). Whereas climate change mitigation consists of actions to limit the magnitude or rate of long term global warming and its related effects. Climate change mitigation generally involves reductions in anthropogenic emissions of greenhouse gasses (GHGs).

\subsection{Sources of GHG emissions from Agriculture}

Ethiopia is one of the world's lowest emitters of GHG emissions, ranking 182 of 188 countries on per capita emissions and contributing only $0.27 \%$ of global emissions (MOFAN, 2018). 
Today's per capita emissions of less than $2 \mathrm{t} C O 2 \mathrm{e}$ are modest compared with the more than $10 \mathrm{t}$ per capita on average in the European Union (EU) and more than $20 \mathrm{t}$ per capita in USA and Australia (Zegeye, 2018).

According to Engdaw (2020), except land use and land cover changes in forestry, Ethiopia has shown increasing trends of emission in most sectors. However, land use and change and forestry is the first leading sector that has contributed to the largest greenhouse gases emission in the country (Figure 1).

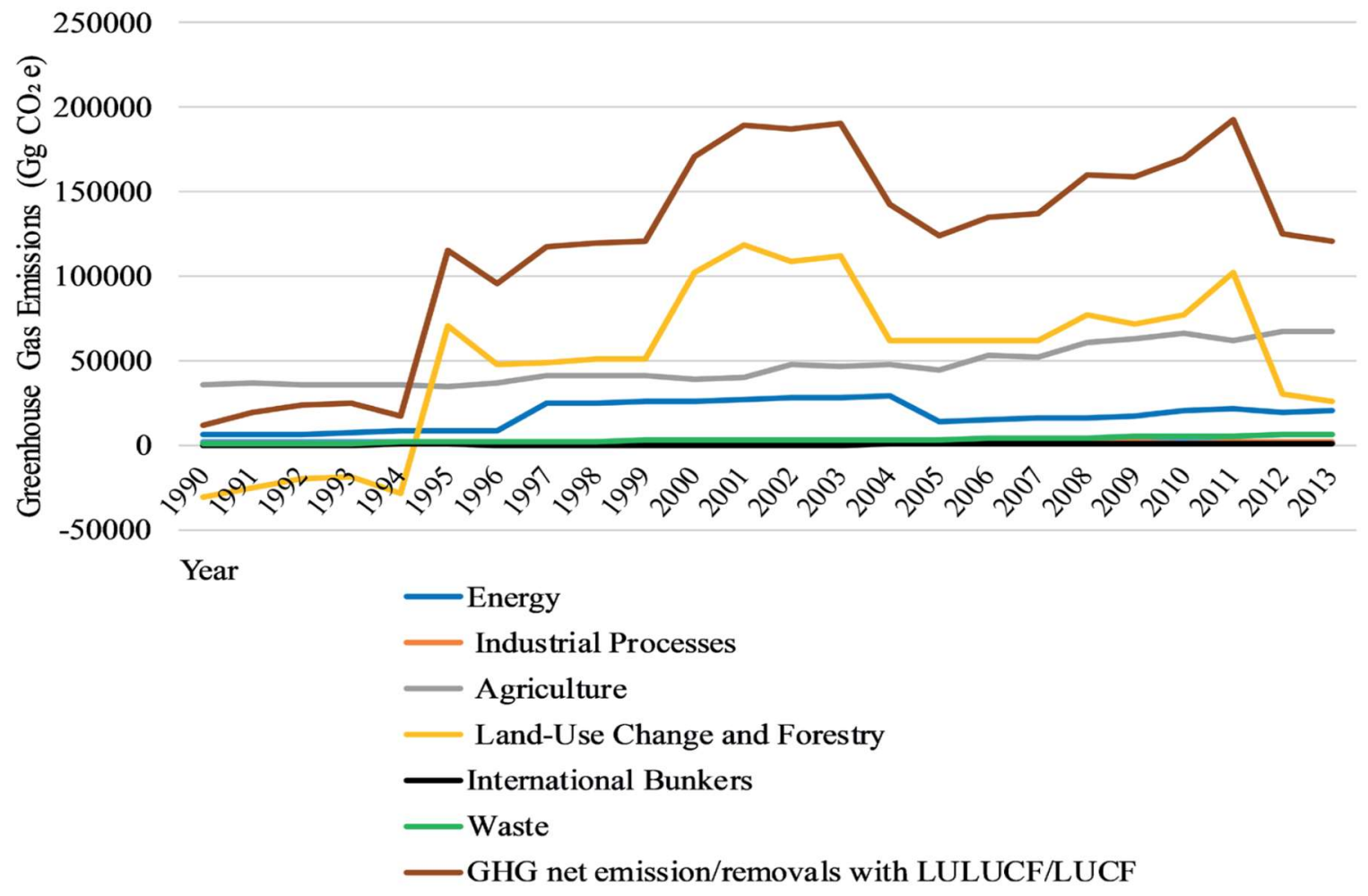

Figure 1. Trends of greenhouse gas emission in terms of sectors (1990-2013) (Engdaw, 2020)

Having an average emission of $50739.7 \mathrm{GgCO}_{2} \mathrm{e}$, land use and land cover change and forestry is the largest sector that contributes to greenhouse gas emissions in Ethiopia. The agricultural sector played the second largest role with an average emission level of $47093.63 \mathrm{GgCO}_{2} \mathrm{e}$. Following the above two sectors, the energy sector that ranked third has contributed an emission of $17670.13 \mathrm{GgCO}_{2} \mathrm{e}$. Other sectors like waste, industrial, and international bunkers have contributed a trivial amount to the country's greenhouse gas emissions, with average greenhouse gas emissions of $3081.21 \mathrm{GgCO}_{2} \mathrm{e}, 881.21 \mathrm{GgCO}_{2} \mathrm{e}$, and $458.65 \mathrm{GgCO}_{2} \mathrm{e}$, respectively (Engdaw, 2020). 
In Ethiopian agriculture in 2012 for instance, the major sources GHG emissions are indicated in Figure (2). The largest proportion of emissions results from enteric fermentation (53\%) followed by manure left on pasture (37\%), both of which are related to livestock production. But, the least emitters in Ethiopian agriculture are rice cultivation, burning crop residues, manure applied on soil, and crop residues (FAO, 2016).

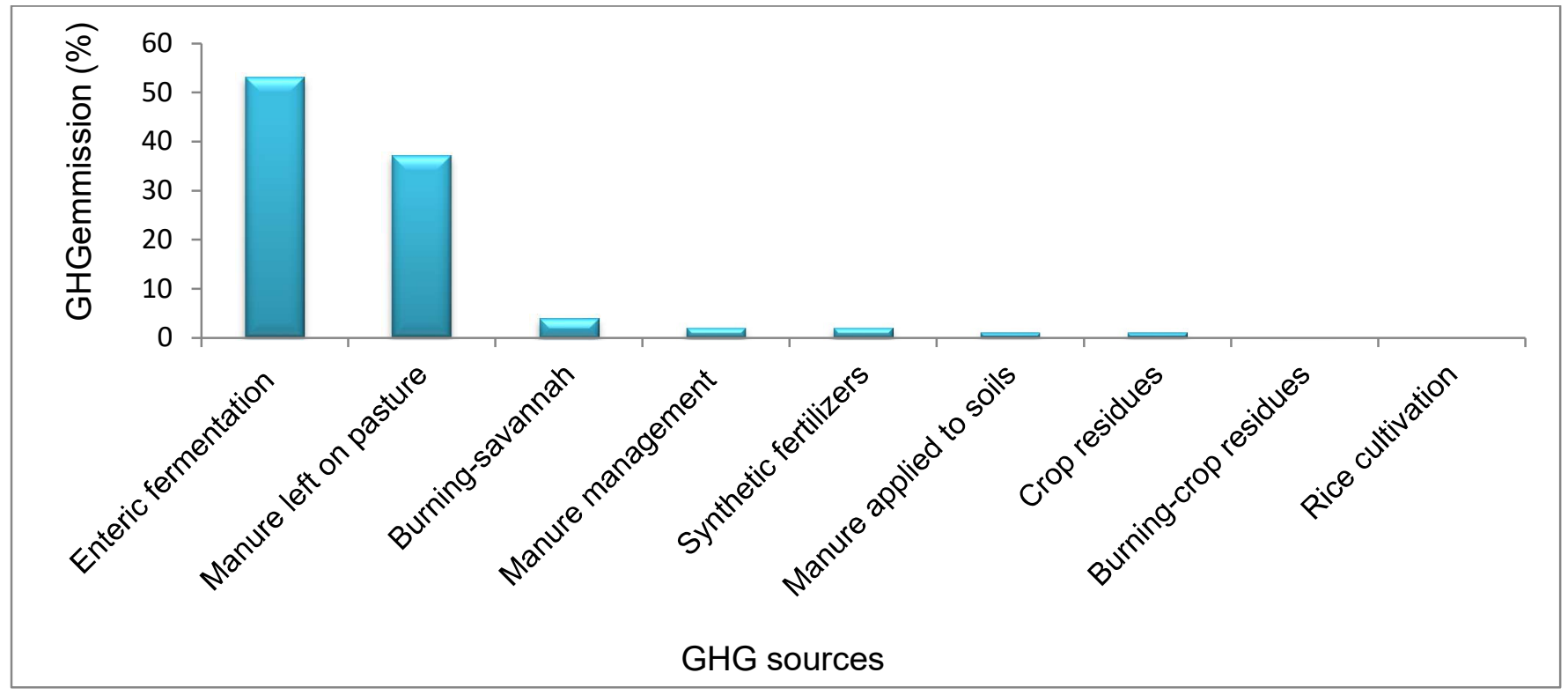

Figure 2. GHG emissions in Ethiopian agriculture in 2012 (FAO, 2016)

Moreover, the share of GHG emission from urban production system was $58.4 \%$ compared to $22.14 \%$ mixed crop- livestock and $18.6 \%$ pastoral production system (Berhe and Bariagabre, 2020). Their study also shows $83.42 \% \mathrm{CH}_{4}$ was emitted from the systems. The rest $16.6 \%$ of the production systems was constituted by $\mathrm{CO}_{2}$ and $\mathrm{N}_{2} \mathrm{O}$ GHG gases (Table 1).

Table 1. Contribution of the different modules of the GHG from the three production systems (\%) (Berhe and Bariagabre, 2020)

\begin{tabular}{lllll}
\hline GHG emission & PPS & MLPS & UPS & (\%) of total \\
\hline $\mathrm{CO}_{2}$ & 0.79 & 2.94 & 5.75 & 4.18 \\
$\mathrm{CH}_{4}$ & 74.77 & 83.93 & 85.97 & 83.42 \\
$\mathrm{~N}_{2} \mathrm{O}$ & 24.44 & 13.13 & 8.28 & 12.40 \\
\hline$\%$ of total & 18.59 & 22.14 & 58.44 & 100 \\
\hline \multicolumn{2}{l}{ Notes: PPS: pastoral production system, MLPS: mixed crop-livestock production system and UPS: urban production system }
\end{tabular}

\section{Climate smart agricultural practices in Ethiopia}

Climate smart agricultural (CSA) practices are practices that sustainably increase productivity, enhance resilience, remove GHGs, and enhance achievement of national food security and 
development goals (FAO, 2010). There are different climate smart agricultural practices in Ethiopia (FAO, 2016). These practices consist different components and used for specific purposes in GHG emission mitigation and climate change adaptation (Table 2).

Table 2. Summary of some common CSA practices in Ethiopia (FAO, 2016)

\begin{tabular}{|c|c|c|}
\hline CSA practice & Components & Why it is climate smart \\
\hline $\begin{array}{l}\text { Conservation } \\
\text { agriculture }\end{array}$ & $\begin{array}{l}\text { - } \quad \text { Reduced tillage } \\
\text { Crop residue management - mulching, } \\
\text { intercropping } \\
\text { Crop rotation/intercropping with cereals } \\
\text { and legumes }\end{array}$ & $\begin{array}{ll}\text { - } & \text { Carbon sequestration } \\
\text { - } & \text { Reduce existing emissions } \\
\text { - } & \text { Resilience to dry and hot spells }\end{array}$ \\
\hline $\begin{array}{l}\text { Integrated soil } \\
\text { fertility management }\end{array}$ & $\begin{array}{l}\text { Compost and manure management, } \\
\text { including green manuring } \\
\text { Efficient fertilizer application techniques } \\
\text { (time, method, amount) }\end{array}$ & $\begin{array}{ll}\text { - } & \text { Reduced emission of nitrous } \\
\text { oxide and } \mathrm{CH}_{4} \\
\text { - } \quad \text { Improved soil productivity }\end{array}$ \\
\hline Small-scale irrigation & $\begin{array}{ll}\text { - } & \text { Year-round cropping } \\
\text { - } & \text { Efficient water utilization }\end{array}$ & $\begin{array}{ll}\text { - } & \text { Creating carbon sink } \\
\text { - } & \text { Improved yields } \\
\text { - } & \text { Improved food security } \\
\end{array}$ \\
\hline Agroforestry & $\begin{array}{l}\text { - } \quad \text { Tree-based conservation agriculture } \\
\text { - } \quad \text { Practiced both traditionally and as } \\
\text { improved practice } \\
\text { - } \quad \text { Farmer-managed natural regeneration } \\
\end{array}$ & $\begin{array}{l}\text { - Trees store large quantities of } \\
\mathrm{CO}_{2} \\
\text { - Can support resilience and } \\
\text { improved productivity of } \\
\text { agriculture } \\
\end{array}$ \\
\hline Crop diversification & $\begin{array}{ll}\text { - } & \text { Popularization of new crops and crop } \\
\text { varieties } \\
\text { - } \\
\text { Pest resistance, high yielding, tolerant to } \\
\text { drought, short season }\end{array}$ & $\begin{array}{ll}\text { - } & \text { Ensuring food security } \\
\text { - } & \text { Resilience to weather variability } \\
\text { - } & \text { Alternative livelihoods and } \\
\text { improved incomes }\end{array}$ \\
\hline $\begin{array}{l}\text { Improved livestock } \\
\text { feed and feeding } \\
\text { practices }\end{array}$ & $\begin{array}{ll}\text { - } & \text { Reduced open grazing/zero grazing } \\
\text { - } & \text { Forage development and rangeland } \\
\text { management } \\
\text { - } & \text { Feed improvement } \\
\text { - } & \text { Livestock breed improvement and } \\
\text { diversification }\end{array}$ & $\begin{array}{ll}\text { - } & \text { Improved livestock productivity } \\
\text { - } & \text { GHG reduction } \\
\text { - } & \mathrm{CH}_{4} \text { reduction }\end{array}$ \\
\hline Other & $\begin{array}{ll}\text { - } & \text { In situ } \text { water conservation/harvesting } \\
\text { - } & \text { Early-warning systems and improved } \\
\text { - } & \text { Supather information } \\
\text { - } & \text { Stoves, biofuels } \\
\text { - } \quad \text { Livelihoods diversification (apiculture, } \\
\text { - } \quad \text { aquaculture) } \\
\text { Post-harvest technologies (agro- } \\
\text { processing, storage) }\end{array}$ & $\begin{array}{ll}\text { - } & \text { Resilience of agriculture } \\
\text { - } & \text { Improved incomes } \\
\text { - } & \text { Reduced emissions } \\
\text { - } & \text { Reduced deforestation } \\
& \text { Reduced climate risk }\end{array}$ \\
\hline
\end{tabular}

Various types of traditional climate smart agricultural (CSA) practices have also been implemented and adopted in Ethiopia. Such practices include the Derashe traditional conservation agriculture, Konso cultural landscape, and traditional agroforestry in Gedeo Zone, East Shewa Zone, East Wollega Zone, and West Gojam Zone, Hararghe highland traditional soil and water conservation, Hararghe cattle fattening and Hararghe small-scale traditional irrigation 
in East Ethiopia, and Ankober manure management in the Northern parts of the country (FAO, 2016).

\subsection{Mitigation potential of climate smart agricultural practices for GHG emissions}

Agriculture can play an important role in climate change mitigation while contributing to increased food security and reductions in rural poverty (FAO, 2012). Widespread adoption of climate smart agriculture (CSA) has the potential to greatly mitigate agricultural greenhouse gas (GHG) emissions by increasing soil organic carbon (SOC) stocks and decreasing nitrous oxide (N2O) emissions (McNunn et al., 2020). According to IFAD (2019), combination of the adoption of climate smart agricultural (CSA) practices such as no tillage, increased crop diversity and retaining crop residue on farm have a mitigation potential/or increased SOC in non-flooded crops that change in significant ton of $\mathrm{CO}_{2} \mathrm{e} \mathrm{ha}^{-1}$ year- $^{-1}$. In addition, a mitigation potential of $\mathrm{CH}_{4}$ in reduced irrigation of paddy rice farms was also changed in ton $\mathrm{CO}_{2} \mathrm{e} \mathrm{ha}^{-1}$ year-1 (Figure 3).

Mitigation practices that increase animal productivity generally also increase emissions but decrease $\mathrm{CH}_{4}$ per unit of animal product (emission intensity). For instance, Thornton and Herrero (2010) found that productivity enhancing interventions in the tropics could reduce emission intensity in dairy systems by up to 0.9 t $\mathrm{CO}_{2}$ e per milk. IFAD (2019) also depicts agroforestry practices and addition of organic fertilizers on the farm increased mitigation potential of 784093 $\mathrm{t} \mathrm{CO}_{2} \mathrm{e}$ and $193050 \mathrm{t} \mathrm{CO}_{2} \mathrm{e}$ biomass of carbon and SOC per year respectively (Figure 4). 


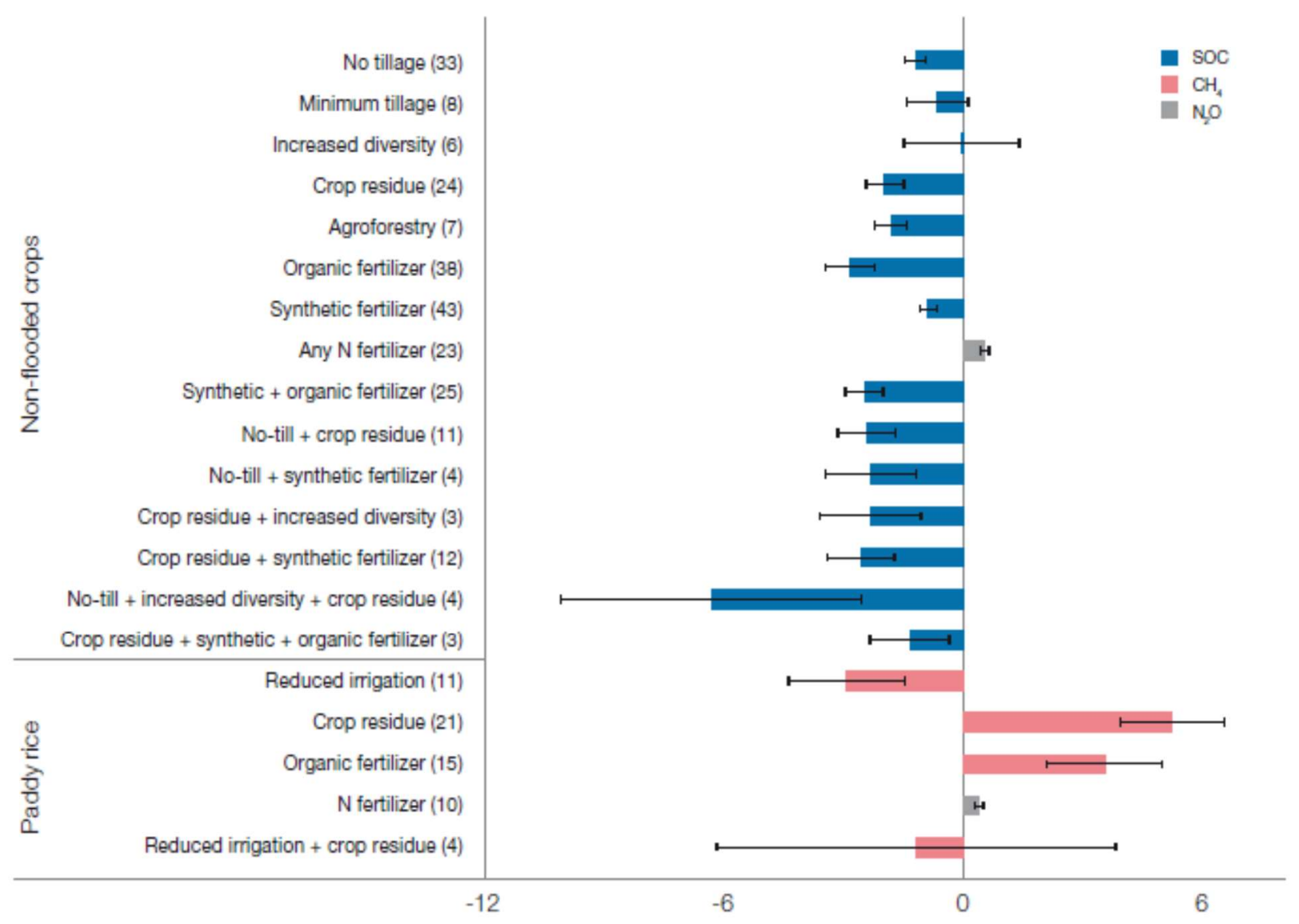

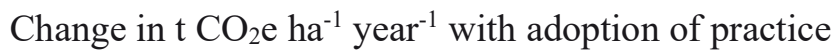

Figure 3. Mitigation potential of climate-smart practices (Negative values represent a reduction in GHG emissions (or carbon sequestration). Values in parentheses are the number of studies. Positive values represent an increase in GHG emissions, rather than mitigation). (Source: IFAD, 2019) 


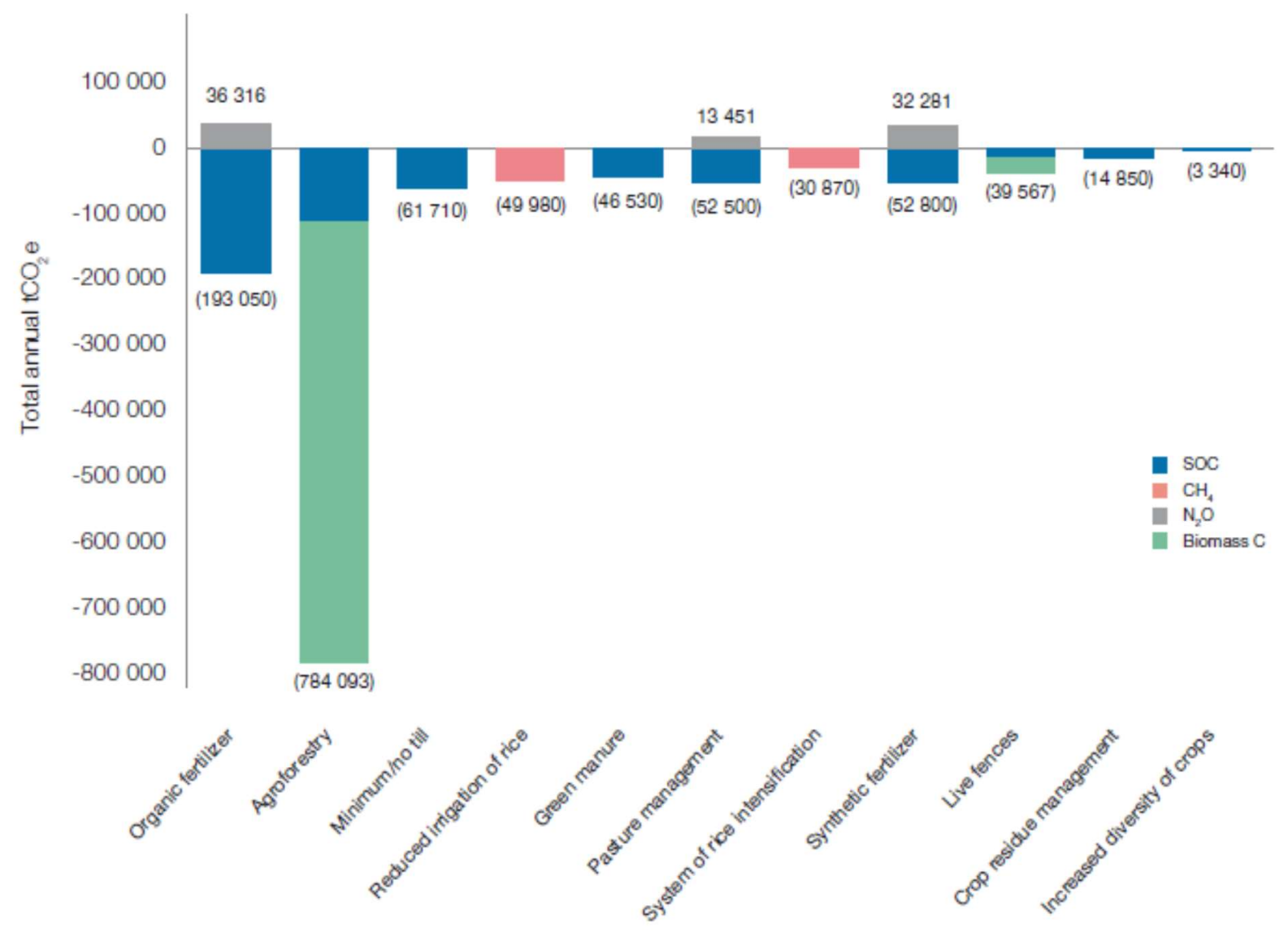

Figure 4. Total effect on GHG emissions of improved agricultural practices within IFAD's investment portfolio during the IFAD period (2011-2014). Negative values represent a reduction in GHG emissions (or carbon sequestration). Positive values represent an increase in GHG emissions. (Source: IFAD, 2019)

\subsection{Determinant of climate smart agricultural practices in mitigation of GHG emissions}

One of the major strategies of adoption and diffusion of various climate smart agricultural (CSA) practices for improving crop and livestock production, and farmer income while reducing greenhouse gas emissions. However, adoptions of climate smart agricultural (CSA) practices are affected by different factors. These could be due to farming factors (farm size), technology inaccessibility, environmental factors, policy design and social expertise, negative attitudes and motivations of farmers, farmers' socio-demographic factors, and farmers' socioeconomic factors (Teklewold et al., 2019). Education status of the farmers and access to extension and weather information can also influence the likelihood of adopting these practices (Issahaku and Abdulai, 2019). 
Diallo et al. (2019) show that adoption of various climate smart agricultural (CSA) strategies was significantly influenced by socioeconomic, infestation of pests, credit access, institutional and climate related factors. Moreover, several factors, including household characteristics, plot characteristics, market access and major climate risks are found to affect the probability and level of adoption of the various climates smart agricultural (CSA) practices (Aryal et al., 2018).

\section{Conclusions}

In Ethiopia, several traditional and adopted climates smart agricultural (CSA) practices carried out by farmers in different agro-ecologies. However, little research information is available for different stakeholders for wider scale out and scale up of the technologies. Among the climate smart agricultural (CSA) practices, agroforestry, conservation agriculture, intensive livestock husbandry, integrated soil fertility management, area closure for restoration of wetlands and degraded lands, participatory forest management practices are the best practices that sustain the ecosystem services, mitigation of greenhouse gases (GHGs), and ultimately improve incomes of households and alleviate poverty in the country.

Combinations of the best adopted climate smart agriculture practices have high potential in mitigation of greenhouse gases. Integration conservation tillage practices with crop diversity on the farmlands play a great role in reduction of GHG emissions. Moreover, enhancing the productivity of livestock could also reduce the intensity of GHG emissions into the atmosphere. But, different adoptions of climate smart agricultural practices are affected by different factors have implications of continuous emissions of GHGs.

To reverse the situations of climate change, so many adaptation options should be designed. For instance, adoption of climate smart agricultural (CSA) technologies, farmers are encouraged to join community farmer groups to enhance extension service provision through these groups. For extension services, farmers that are using the best traditional and adopted climate smart agricultural (CSA) practices should be clustered for the purpose of agricultural production activities and mitigation of GHG on their farm plots. These farmers can be used as model farmers for agriculture and natural resources management practices. Preparation of targeted climate smart agricultural (CSA) practices to areas that are likely to provide the greatest GHG reduction potential and demonstration of the practices to other areas should be encouraged so that other farmers will learn for similar agro-ecologies. In addition, further multidisciplinary 
researches on climate smart agricultural (CSA) practices should be carried out to select the best technologies at different stakeholder levels in the country.

\section{Acknowledgment}

The author thanks to Arba Minch University for supporting the document to be prepared.

\section{References}

Abegunde, O.V., Sibanda, M., Ajuruchukwu O., 2019. Determinants of the adoption of climate-smart agricultural practices by small-scale farming households in King Cetshwayo District Municipality, South Africa. Sustainability 12 , 195; doi: 10.3390/su12010195.

Adem, M., Tadele, E., Mossie, H., Ayenalem, M., 2018. Income diversification and food security situation in Ethiopia: A review study. Cogent Food \& Agriculture 4, 1513354, https://doi.org/10.1080/23311932.2018.1513354.

Arfin, T., Aquatar, O.M., Waghmare, S.S., 2015. Mitigation strategies to greenhouse gas emission control: a database for emission factors. International Journal for Scientific Research \& Development 10, 908-917.

Arora, K.N. 2019. Impact of climate change on agriculture production and its sustainable solutions. Environmental Sustainability 2, 95-96, https://doi.org/10.1007/s42398-019-00078-w.

Aryal, P.J., Rahut, B.D., Maharjan, S., Erenstein, O., 2018. Factors affecting the adoption of multiple climate-smart agricultural practices in the Indo-Gangetic Plains of India. Natural Resources Forum 42, 141-158, doi: 10.1111/1477-8947.12152.

Berhe, A., Bariagabre, A.S., 2020. Estimation of greenhouse gas emissions from three livestock production systems in Ethiopia. International Journal of Climate Change Strategies and Management, doi; 10.1108/IJCCSM09-2019-0060.

Brevik, C.E., 2013. The potential impact of climate change on soil properties and processes and corresponding influence on food security. Agriculture 3, 398-417; doi: 10.3390/agriculture3030398.

Daba, H.M., Bazi, Z., Belay, A., 2018. Effects of Climate Change on Soil and Water Resources: A Review. Journal of Environment and Earth Science 8, 71-80.

Dendir, Z., Simane, B., 2019. Livelihood vulnerability to climate variability and change in different agroecological zones of Gurage Administrative Zone, Ethiopia. Progress in Disaster Science 3, http://dx.doi.org/10.1016/j.pdisas.2019.100035.

Diallo, M., Aman, J.N., Adzawla, W., 2019. Factors influencing the adoption of climate smart agriculture by farmers in Ségou region in Mali. In: the Conference on Climate Change and Food Security in West Africa, University Cheikh Anta Diop de Dakar (UCAD) and Center for Development Research (ZEF), University of Bonn, on 17-18 November 2019 in Dakar, Senegal.

Engdaw, D.B., 2020. Assessment of the trends of greenhouse gas emission in Ethiopia. Geography, Environment, Sustainability 13, 135-146, https://doi-10.24057/2071-9388-2018-61.

FAO 2010. "climate-smart" agriculture: policies, practices and financing for food security, adaptation and mitigation. Paper prepared for Hague Conference on agriculture, food security and climate change.

FAO, 2012. The Carbon footprint of the agricultural growth project (AGP) in Ethiopia: An application of the exante carbon-balance tool (EX-ACT). In: Bockel L, Branca G (Ed.), Viale delle Terme di Caracalla, 00153 Rome, Italy.

FAO., 2016. Ethiopia Climate-Smart Agriculture Scoping Study. In: Jirata et al. (Eds.), Ethiopia.

Gezie M (2019) Farmer's response to climate change and variability in Ethiopia: A review. Cogent Food \& Agriculture, 5, 1613770, https://doi.org/10.1080/23311932.2019.1613770.

IPCC, 2013. Climate Change: the Physical Science Basis. Contribution of Working Group I to the Fifth Assessment Report of the Inter-governmental Panel on Climate Change. Cambridge University Press, Cambridge, UK.

International Fund for Agricultural Development (IFAD) (2019). Climate change mitigation potential of agricultural practices supported by IFAD investments: An ex ante analysis. The IFAD Research Series, Benfica R, Gillman H, Lesa A, Vaid S (Ed.) pp4-9.

Issahaku, G., Abdulai, A., 2019. Adoption of climate-smart practices and its impact on farm performance and risk exposure among smallholder farmers in Ghana. Australian Journal of Agricultural and Resource Economics, 64, 396-420, doi: 10.1111/1467-8489.12357. 
Jantke, K., Hartmann, J.M., Rasche, L., Blanz, B., Schneider, A.U., 2020. Agricultural Greenhouse Gas Emissions: Knowledge and Positions of German Farmers. Land 9,130; doi: 10.3390/land9050130.

Karmakar, R., Das, I., Dutta, D., Rakshit, A., 2016. Potential Effects of Climate Change on Soil Properties: A Review. Sci. Int. 4, 51-73, doi: 10.17311/sciintl.2016.51.73.

Komarek, M.A., Thurlow, J., Koo, J., Pinto, D.A., 2019. Economy wide effects of climate-smart agriculture in Ethiopia. Agricultural Economics, 50, 765-778.

Lemi, T., Hailu, F. 2019. Effects of climate change variability on agricultural productivity. Int J Environ Sci Nat Res.; 17, 555953. doi: 10.19080/IJESNR.2019.17.555953.

McNunn, G., Karlen, L.D., Salas, W., Rice, W.C., Mueller, S., Jr, M.D., Seale, W.J., 2020. Climate smart agriculture opportunities for mitigating soil greenhouse gas emissions across the U.S. Corn-Belt. Journal of Cleaner Production 268, 122240, https://doi.org/10.1016/j.jclepro.2020.122240.

Ministry of Foreign Affairs of the Netherlands (MOFAN)., 2018. Climate change profile Ethiopia. 201817BUZ108158 | E, The Hague | The Netherlandswww.government.nl/foreign-policy-evaluations.

Neufeld, H., Jahn, M., Campbell, B.M., Beddington, J.R., DeClerck, F., De Pinto, A., Gulledge, J., Hellin, J., Herrero, M., Jarvis, A., LeZaks, D., Meinke, H., Rosenstock, T., Scholes, M., Scholes, R., Vermeulen, S., Wollenberg, E., Zougmore, R., 2013. Beyond climate smart agriculture: Toward safe operating spaces for global food systems. Agriculture \& Food Security 2, 12. https://doi.org/10. 1186/2048-7010-2-12.

Niles, M.T., Ahuja, R., Barker, T., Esquivel, J., Gutterman, S., Heller, C.M., Mango, N., Portner, D., Raimond, R., Tirado, C., Vermeulen, S., 2018. Climate change mitigation beyond agriculture: A review of food system opportunities and implications. Renewable Agriculture and Food Systems https://doi.org/10.1017/S1742170518000029.

Simane, B., Beyene, H., Deressa, W., Kumie, A., Berhane, K., Samet, J., 2017. Review of climate change and health in Ethiopia: status and gap analysis. Ethiop J Health Dev., 30, 28-41.

Sustainable Land Management (SLM), 2017. Climate Smart Agriculture (CSA) a manual for implementing the sustainable land management program (SLMP). In Deichert G, Gobena GA, Blum L, Mr. Kersting D (Ed). pp5, Addis Ababa, Ethiopia.

Teklewold, H., Gebrehiwot, T., Bezabih, M., 2019. Climate smart agricultural practices and gender differentiated nutrition outcome: An empirical evidence from Ethiopia. World Development 122, 38-53, https://doi.org/10.1016/j.worlddev.2019.05.010.

The International Food Policy Research Institute (IFPRI), 2010. Hydro-economic modeling of climate change impacts in Ethiopia in You G, Ringler C (Ed). IFPRI Discussion Paper 00960.

Thornton, P.K., Herrero, M., 2010. "Potential for reduced methane and carbon dioxide emissions from livestock and pasture management in the tropics.” Proc. Natl. Acad. Sci. 107, 19667-19672.

United States Agency for International Development (USAID), 2015. Climate variability and change in Ethiopia: summery of findings in Zermoglio F, Steynor A, Jack C (Ed). Technical reports.

Zegeye, H., 2018. Climate change in Ethiopia: impacts, mitigation and adaptation. International Journal of Research in Environmental Studies 5, 18-35. 